\title{
Correlation Between Exposure to Transfluthrin and the Change in Dielectric Properties and Deformed Cells of Mice
}

\author{
Unggul Pundjung Juswono ${ }^{1 *}$, Arinto Yudi Ponco Wardoyo ${ }^{2}$, \\ Chomsin Sulistya Widodo ${ }^{1}$, Johan Andoyo Effendi Noor ${ }^{1}$, Didik Rahadi Santoso ${ }^{1}$ \\ 'Laboratory of Advanced Physics, Department of Physics, Brawijaya University, \\ Jalan Veteran, Malang, Indonesia 65145 \\ ${ }^{2}$ Laboratory of Air Quality and Astro Imaging, Department of Physics, Brawijaya University, \\ Jalan Veteran, Malang, Indonesia 65145
}

Received: 28 October 2019

Accepted: 18 April 2020

\begin{abstract}
Transflutrhin is a single isomer compound that is contained in mosquito repellent. The volatility of this chemical compound made it suited for applications that evaporate this active ingredient like space spray using one push mosquito repellent. As an aerosol, transfluthrin can trigger oxidative stress that causes cell damage. Cell damage can be identified microscopically or by analyzing the electrical characteristics of the cell. Cell damage due to the content of chemical compounds in the pollutants that enter the body will affect the electrical properties of the cell itself. One of the bio-electric variables in organ tissues that can be analyzed and used to determine the level of tissue damage is a change in the dielectric constant value of an organ. The measurement of the dielectric constant is done by using two conductor plates in which the dielectric material is inserted in the middle of the plates, and the capacitance value will be measured. The results show that a higher level of damage to the organ caused a lower dielectric constant value. This decrease was caused by the changes in the polarization properties of the damaged tissue. Factors that affected the polarization of material were large electric dipole moments and large numbers of healthy and damaged cells. Organ damage was determined based on the decrease in the value of dielectric constant. Histological studies revealed severe cell damages evidenced by the deformed cell compared to the unexposed mice. Type-A mosquito repellents with transfluthrin active ingredients of $25 \%$ caused $74 \%$ at lung cell damage, $71 \%$ of blood damage, $47 \%$ of kidney cell damage, and $40 \%$ of liver cell damage, with dielectric organ constants $0.65 \times 10^{5}$ to $2.62 \times 10^{5}$. In the mice exposed to type-B mosquito repellent ( $21.3 \%$ of transfluthrin), the damage levels were $72 \%$, $72 \%, 49 \%$, and $36 \%$, respectively, for lung, blood, kidney, and liver cells. The dielectric constants were $0.91 \times 10^{5}$ to $2.62 \times 10^{5}$. Our studies indicate that mosquito repellent aerosol does initiate physical damage
\end{abstract}

*e-mail: unggul-pj@ub.ac.id 
to the cells of mice. These histological studies must be taken into consideration by the use of mosquito repellent, particularly when investigating the long-term effect of the transfluthrin impact on health.

Keywords: cell damage, dielectric constant, mosquito repellent, transfluthrin

\section{Introduction}

The increasing amount of pollutant concentrations in the ambient air becomes a serious issue in environmental quality change. The activities of human life provide a lot in the decreasing qualities of air, land, and water and affect human health, animal, and plant life. All forms of pollutants are very dangerous for human health. Once they enter the body through a respiratory process or oral process, they have the potential to interfere with organ function $[1,2]$.

Indonesia is one of the largest archipelagic countries with a tropical climate. The negative impact caused by this climate is the emergence of epidemics caused by mosquito bites such as malaria and dengue fever [3, 4]. The spread of mosquitoes that cause malaria and dengue fever can be prevented by using insect repellent, such as mosquito repellent. Mosquito repellent contains toxic active ingredients [5].

Transfluthrin is one of the mosquito repellent active ingredients [6, 7]. This substance is a type of insecticide belonging to the synthetic pyrethroid group [5]. Transfluthrin, which enters the body, can trigger the formation of free radicals. Generally, free radicals can be found as atoms, elements, molecules, or compounds that have one or more unpaired electrons in their outer shell [8]. If these free radicals interact with body cells, it may cause abnormalities in organs [9].

Cell damage from organs can be caused by oxidative stress and the relation with inflammation [10]. Oxidative stress is a pathological condition that is associated with the increased speed of cell and tissue damage due to the induction of oxygen and its derivatives or ROS (Reactive Oxygen Species) [11]. Cell damage occurs due to an imbalance in the amount of ROS and the physiological activity of antioxidants in the body against these free radicals [12]. The production of ROS and inflammatory cytokines in the body indicates injuries or dysfunction in cells due to many toxic reasons, such as found in hepatocytes (liver cells) and lung cells $[13,14]$.

Cell damage due to the content of chemical compounds in the pollutants that enter the body will affect the cell's electrical properties. Bioelectricity is a characteristic possessed by cells or biological tissue and can be defined as electrical conductivity, dielectric constant, capacitance, inductance, and impedance [15-17]. The electrical cells of living things are regulated through the compound activity of biological metabolism and ion exchange in the body. The electricity of a material or tissue can be assessed based on the conductivity and dielectric dispersion of the material. The change in polarization properties of substances (atoms or molecules) that make up the material will cause changes in conductivity and dielectric dispersion $[15,16]$.

Research carried out on foodstuffs from living things shows that damage to food causes changes in the dielectric properties of these foods. Assuming that the nature and composition of organ tissue are almost similar to the nature of food composition, it can be analogized that changes in tissue conditions will cause changes in the dielectric properties of the tissue. The magnitude of the change in dielectric properties depends on how much damage or conditions occur in the tissue network [18]. The measurement of healthy and atherosclerotic dielectric arteries also shows significant differences.

The bioelectrical properties can be observed using the measurement method for the organ's dielectric constants. The amount measured in this method is the value of capacitance, where the value of the capacitance $C$ is proportional to the value of the dielectric constant $\left(\varepsilon_{r}\right)$. The equation that describes the relationship between capacitance and dielectric constant can be seen below:

$$
\mathrm{C}=\left(\varepsilon_{\mathrm{r}} \cdot \varepsilon_{0} \cdot \mathrm{A}\right) / \mathrm{d}
$$

\section{Experimental}

\section{Mosquito Repellents}

Two types of aerosol spray mosquito repellents that were purchased from the general market were used as the source of transfluthrin. They were determined as type-A (25\% of transfluthrin) and type-B mosquito repellents (23.1\% of transfluthrin). The concentrations of the exposed transfluthrin were divided into five variations: $1,2,3,4$, and 5 sprays.

\section{Experimental Animals}

This study used 110 male mice (12 weeks old, body weight: 23-30 grams). All mice were treated humanely and provided with food and freshwater ad libitum. They were kept in cages with a 12/12 dark-light cycle and acclimatized [19]. After the acclimatization process, all mice were divided into three main groups: one control group and two treatment groups (Table 1). All animal treatment procedures were approved by the Animal Care and Use Committee of Brawijaya University Malang, Indonesia (Ethical Clearance number: 541-KEP-UB). 
Table 1. Animal groups for the experiments.

\begin{tabular}{|c|c|c|c|c|}
\hline Main Groups & Aerosol Types & Subgroup Codes & Number of Sprays & Number of Mice \\
\hline \multirow{5}{*}{ Group A } & \multirow{5}{*}{ Type-A } & A1 & 1 & 10 \\
\hline & & $\mathrm{A} 2$ & 2 & 10 \\
\hline & & A 3 & 3 & 10 \\
\hline & & A4 & 4 & 10 \\
\hline & & A5 & 5 & 10 \\
\hline \multirow{5}{*}{ Group B } & \multirow{5}{*}{ Type-B } & B1 & 1 & 10 \\
\hline & & B2 & 2 & 10 \\
\hline & & B3 & 3 & 10 \\
\hline & & B4 & 4 & 10 \\
\hline & & B5 & 5 & 10 \\
\hline Control & - & Ctrl & - & 10 \\
\hline
\end{tabular}

\section{Transfluthrin Exposure}

All exposure treatments after the acclimatization process were conducted in an exposure chamber with a dimension of 30 (length) x 20 (width) x 20 (height) $\mathrm{cm}^{3}$. The first treatment was conducted for the treatment groups, Group A and Group B. According to Table 1, fifty mice from Group A were divided into five subgroups: A1, A2, A3, A4, and A5 ( $n=10$ per subgroup). A similar treatment was applied in Group B, in which fifty mice of Group B were divided into five subgroups containing ten mice per subgroup (B1, B2, B3, B4, and B5). The classification of these subgroups was related to the number of sprays exposed to the mice. Prior to dosing (in the preliminary study), we found that five sprays were the maximum number of sprays that could be exposed to the mice without causing collapsed mice. As shown in Table 1, the mice from subgroups A1, A2, A3, A4, and A5 were exposed to Type-A mosquito repellent with the concentrations of one spray, two sprays, three sprays, four sprays, and five sprays, respectively. Whereas, subgroup B1 is a group of mice exposed to one spray of type-B mosquito repellent.

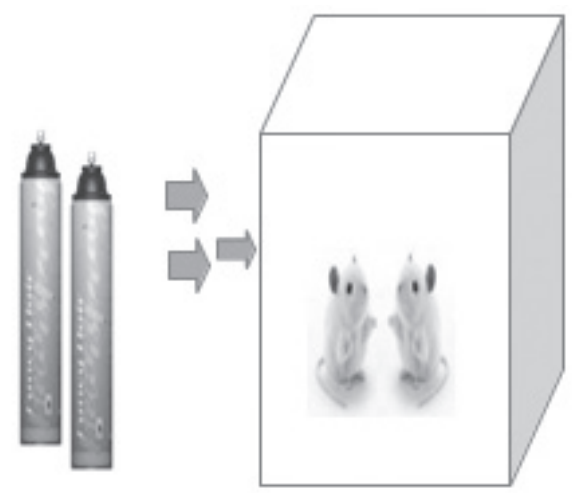

Fig. 1. The set up of the exposure treatments.
For other subgroups, the same method was carried out. After the exposure to the repellents, the mice were kept in the exposure chambers for 20 minutes as the inhalation procedures (Fig. 1) [20]. After exposures, the mice were sacrificed to observe organ samples using the cervical vertebra dislocation method [21].

For the blood samples, the blood was collected in blood tubes. The smears were made on object glasses and fixed with $70 \%$ methanol solutions [22]. After that, they were colored using Giemsa-buffer pro-Giemsa solution (1:3) and washed in freshwater. Meanwhile, the kidneys, livers, and lungs were cleaned using $0.9 \% \mathrm{NaCl}$. They were fixed in buffered formalin for a week before being processed to dehydration process using upgraded ethanol series. After that, the slices were trimmed, processed to the paraffinization, and cut using a microtome. The results were stained using hematoxylin and eosin [19].

\section{Dielectric Test}

An LRC meter was used to measure the capacitance values in the range of $2,000 \mathrm{pF}$ to $20 \mu \mathrm{F}$. The crosssectional area of the plate $(A)$ and the distance between the plates $(d)$ had been measured before, while the

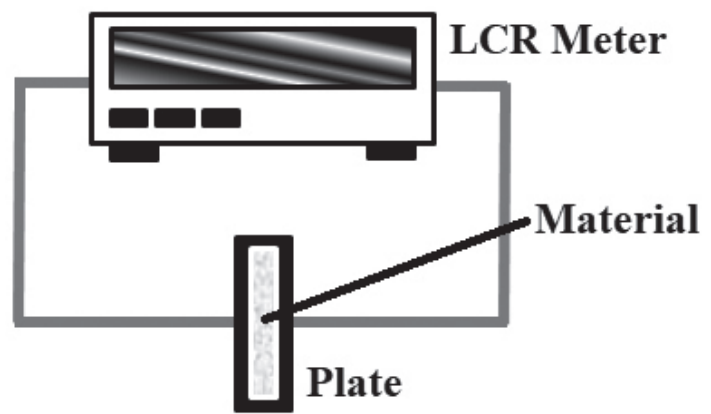

Fig. 2. A series of tools used for the dielectric measurements. 
magnitude of the air permittivity value $\left(\varepsilon_{0}, 8.85 \times 10^{-12}\right.$ $\mathrm{F} / \mathrm{m}$ ) was referred to the reference. The amount of capacitance $C$ was obtained from the measurement results indicated by the capacitance meter with a frequency of 2,000 Hz (Fig. 2). The value of dielectric constant $\varepsilon_{r}$ was calculated using:

$$
\varepsilon_{r}=(C \cdot d) /\left(\varepsilon_{0} \cdot A\right)
$$

\section{Histological Examination}

Digital images of all organs were taken with a 400x magnification of areas from an overall evaluation of the slide. Ten random fields of view were obtained from a Binocular BX-51 Computer Microscope [23]. The damage levels $(D L)[19,24]$ of the mice organs were calculated using:

$$
D L=[\text { [damage cells / Eobserved cells ] x 100\% }
$$

\section{Statistical Analysis}

All data are expressed as the means \pm standard deviation. The association between the dielectric constant and the organ damage level was interpreted by the $2^{\text {nd }}$ order of polynomial regression analysis using Microsoft Excel 2016. $R^{2}>0.90$ was considered as significantly correlated [25].

\section{Results}

The concentrations of the mosquito repellents are shown in Fig. 3 and expressed in the unit of PPM (parts per million). The levels of the repellents were calculated from the repellent mass for each spray $(m)$ and the volume $\left(V_{\text {air }}\right)$ of air inside the exposure chamber. The mass of air inside this chamber $\left(m_{\text {air }}\right)$ was obtained by multiplying the air density $\left(\rho_{\text {air }}\right)$ with $V_{\text {air }}$. of the air mass during the experiment.

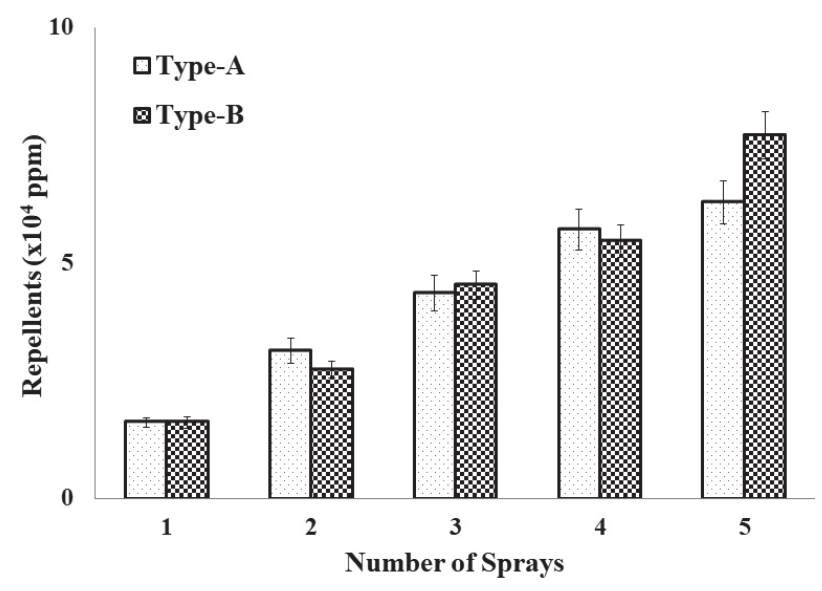

Fig. 3. The concentrations of repellents for each spray.
According to Fig. 3, more spray given to the mice generates a more significant concentration of repellent. This result is related to the level of absorption of active ingredients of mosquito repellent in mice that are also getting higher. Fig. 4 represents the correlation between the dielectric constant and the damage level of the organs $\left(R^{2}>0.90\right)$. There is a strong correlation between the dielectric constants and the damage levels ( $2^{\text {nd }}$ order of polynomial function as the approximation equation). According to Fig. 4, the decreased dielectric constant in organs of the mice exposed to one push aerosol type-B is greater than the decrease found in the type-A group. These results were related to the level of transfluthrin in each repellent type. The active ingredient of transfluthrin in type-B was higher than type-A. Thus, the level of damage in the type-B group was higher than the damage obtained in the type-A group.

Fig. 5 represents the comparison of the physical damages due to the different treatments. According to Fig. 5, the control mice had more healthy cells, with normal form. Besides, the treated mice had more physical damages as the deformation of the cells. The deformation in the red blood cells is mostly found as teardrop-shaped cells, helmet-shaped cells, and drakocyte. In the kidney cells, the deformations are dominated by the narrowed tubules (red circles). Meanwhile, the normal tubules and glomerulus are shown by the white circles and green arrows, respectively. Vein centralist can be found in the hepatocytes, with a large area in white. Parenchymal degeneration and binucleus indicate the cell deformations. In the last observed cell, alveolar cells are indicated by the green circles, while the deformed ones are referred to the blue (ASD, alveolar septal destruction) and yellow circles (edema).

\section{Discussion}

In this study, we found a significant correlation between exposure to transfluthrin with the dielectric changes and cell deformations. Analysis of the possible mechanism involved was based on the study of transfluthrin toxicity and the oxidative stress related to the dielectric changes and cell deformations. This study also shows a significant association between dielectric constants and damage levels.

Transfluthrin is the active ingredient belonging to the pyrethroid group [7, 26]. Pyrethroids in insects are neurotoxins that work by blocking sodium channels in nerve fibers to prevent the transmission of nerve impulses [27]. If toxins enter the body continuously, they may accumulate and cause an impact, such as organ damage. The toxic effects of active chemicals can cause gene mutations, cancer, and even death in cells. Cells are enveloped by membranes whose structure consists of lipids, proteins, and other components. If important cell components (such as proteins, DNA 
a)

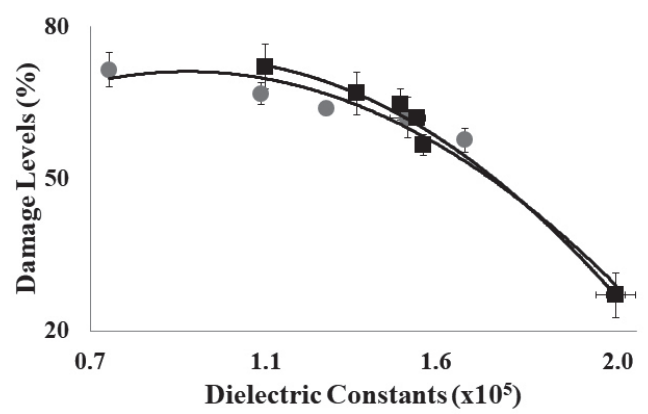

c)

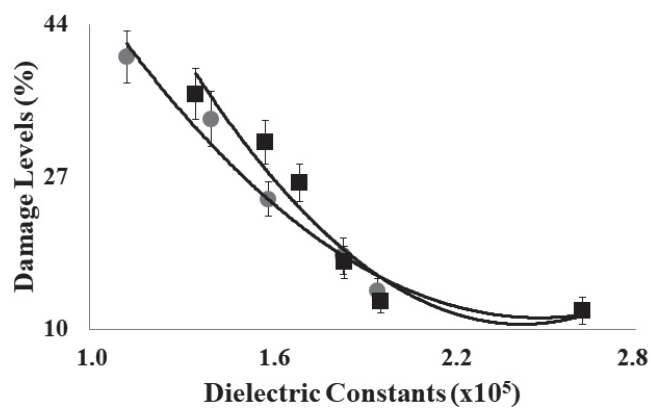

b)

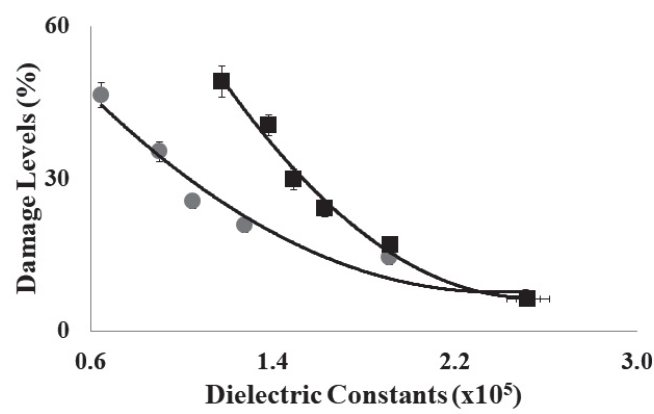

d)

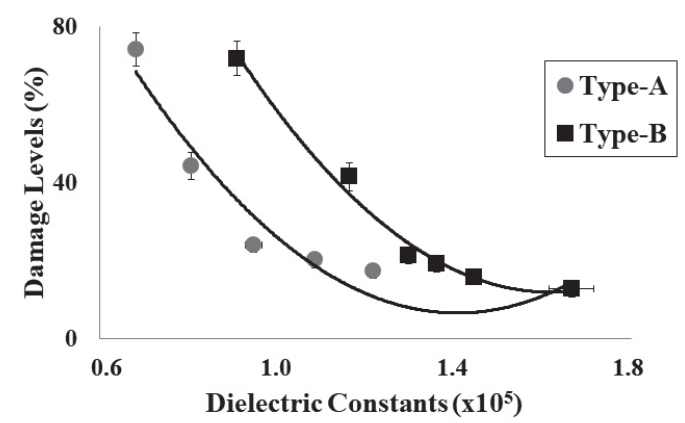

Fig. 4. The correlation between dielectric constant and the damage level of the mice's organs: a). blood $\left(R^{2}=0.96\right.$ and 0.99 , respectively for Type-A and Type-B); b). kidney $\left(R^{2}=0.96\right.$ and 0.98$)$; c). liver $\left(R^{2}=0.98\right.$ and 0.94$)$; and d) lung $\left(R^{2}=0.94\right.$ and 0.99$)$.

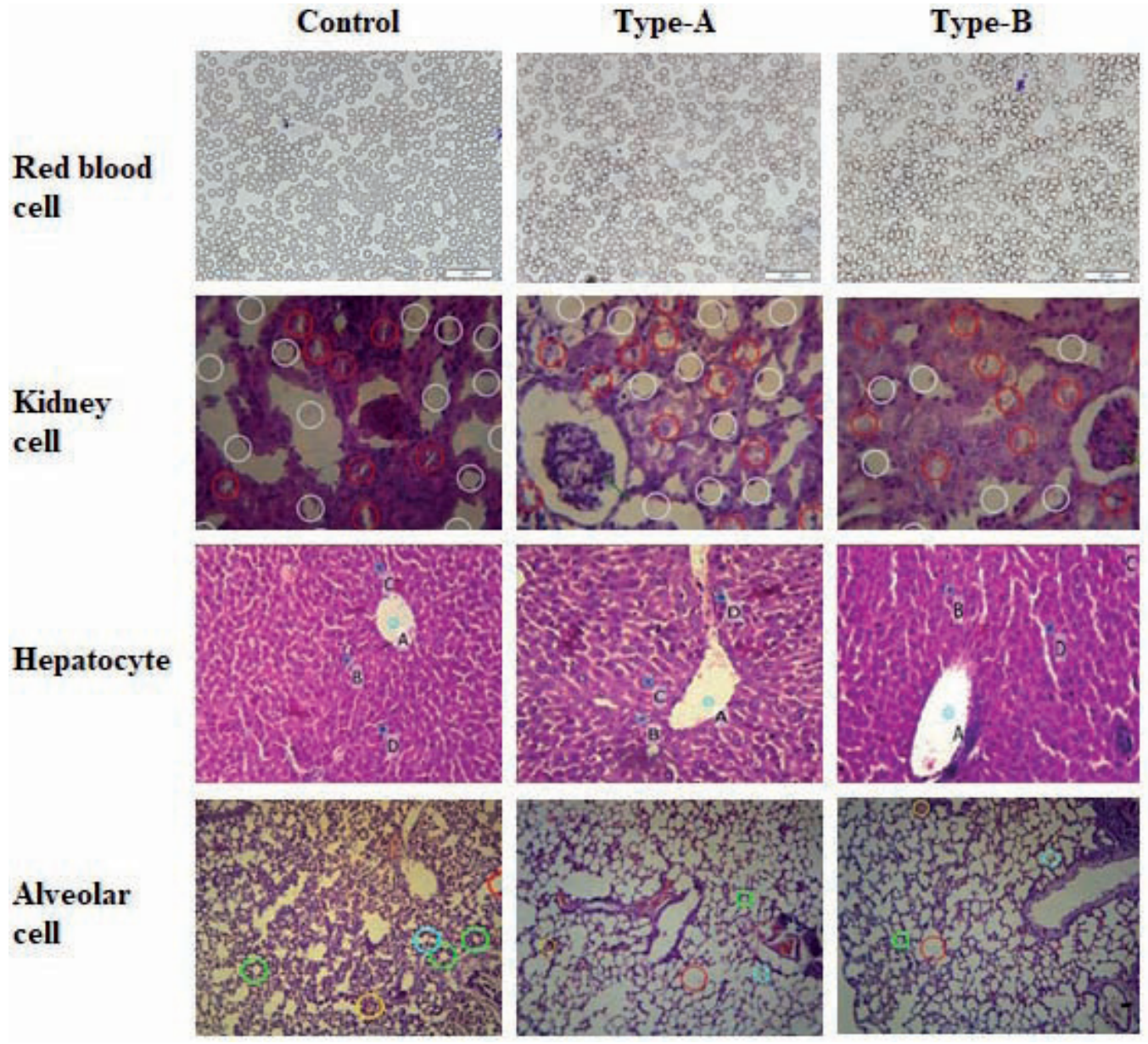

Fig. 5. The physical cell damage (deformation) found in the control and treated mice. 
(deoxyribonucleic acid), and lipids on the membrane) interact with active toxic chemicals, cells can lose their function.

The interaction of transfluthrin with the lungs generally occurs in the blood inside the lungs. In the lungs, there is a bloodstream that contains hemoglobin. Hemoglobin in the blood has a function to bind oxygen. However, oxygen and transfluthrin in the lungs will compete to be bound by hemoglobin. Transfluthrin can be more reactive, so it is easily bound by hemoglobin.

Hemoglobin, which binds to transfluthrin, is carried from the lungs throughout the body, including the spleen organ. Hemoglobin in the blood that transports transfluthrin will be considered as a foreign substance so that lymphoblasts will be activated to produce lymphocytes in follicular follicles. Lymphocytes are white blood cells found in the immune system and are very useful in producing antibodies [28]. If there is continuous damage to blood cells and white blood cells cannot fight it, this may cause toxicity and may trigger the production of free radicals. This interaction can be determined by the existence of oxidative stress and inflammation in the blood. As confirmed in the previous study, there is a relationship between erythrocyte deformability and oxidative stress and chronic inflammation markers [29]. Thus, this interaction probably may become like the blood cell's responses in countering the effects of oxidative stress and chronic inflammation due to free radicals. Oxidation of membrane lipids and proteins may alter the erythrocytes [30]. Also, the presence of free radicals can trigger oxidative stress, which has an impact on organ damage [31]. Organ damage can also be caused by the presence of free radicals or ROS (reactive oxygen species) contained in these organs because ROS has a key role in organ disruption and is related to the inflammatory response [32].

Organ physical damage (e.g., cell deformation) can be seen based on a decrease in the value of the dielectric constant $[33,34]$. The dielectric constant can be used to indicate the nature or characteristics of a material. The dielectric constant describes the degree of polarization of a material [35]. Polarization itself is defined as the repolarization of the electrical charge contained in dielectric materials due to the presence of an external electric field. This polarization results in a parallel electric dipole moment orientation. The dipole moments can be interpreted as a pair of charges that have opposite charges and are separated at a certain distance. The direction of the dipole moment is from a negative charge to a positive charge. The moment of this dipole will determine the amount of polarization that occurs. Several factors influence the polarization of a material, namely the dipole moment and the number of healthy cells and damaged cells $[18,36]$.

Organ damage or reduced healthy cells in the organ will affect the polarization effect or contribute to shifts dielectric spectra $[37,38]$. The more healthy cells in the organ, the greater the level of polarization that will occur. This phenomenon will cause the dielectric constant value to be higher. Conversely, if more cells are damaged, then the polarization that occurs is smaller, so the dielectric constant value gets lower [18]. A decrement in the dielectric constant indicates that the organ is increasingly non-polar. The dielectric constant also depends on electrical susceptibility. Susceptibility describes the degree easiness of polarization of material [35]. So the greater the dielectric constant value, the material is easier to be polarized.

In this study, transfluthrin contained in mosquito repellent, which has an impact on cell damage, may cause a reduction in dipole moments (reducing sample polarity). This decrement will reduce the susceptibility of the sample so that the dielectric constant in the exposed (damaged) organ is also reduced. The relationship between susceptibility and the dielectric constant is shown by the equation below:

$$
C=\left(\varepsilon_{0} \cdot \varepsilon^{\prime} \cdot A\right) / d
$$

With $\varepsilon^{\prime}=1+\chi_{e}$, where $\chi_{e}$ is a susceptibility which is influenced by the number of atoms or the number of molecules involved in polarization and the value of dipole moment.

This study has been conducted in a simple method and analysis. The results show preliminary physical damage of cells related to the obtained dielectric change due to exposure to transfluthrin, as a highlight of the study. However, there is a limitation to identify further physical damage types. Furthermore, analytical procedures focused on the chemical compounds of the repellent should be discussed deeply. A study about dielectric constant and physical damage due to exposure to transfluthrin contained in repellent may be difficult to quantify unless specific assays are developed.

\section{Conclusions}

According to the results above, it is concluded that the active ingredient of transfluthrin contained in mosquito repellents have a negative impact in the form of organ damage in male mice. The organ damages, in terms of the decrease of the organ's dielectric constant, are related to the transfluthrin contents and the mosquito repellent concentrations. Type-A mosquito repellents with transfluthrin active ingredients of $25 \%$ cause $74 \%$ damage in lung cells, $40 \%$ in liver cells (hepatocytes), $47 \%$ in kidney cells, and $71 \%$ in erythrocytes, with the dielectric constants $0.65 \times 10^{5}$ to $2.62 \times 10^{5}$. Type-B mosquito repellent (transfluthrin: $21.3 \%$ ) causes damage in erythrocytes, hepatocytes, alveolar cells, and kidney cells with the percentages of $72 \%, 36 \%, 72 \%$, and $49 \%$, respectively. The dielectric constants type-B group were in the range of $0.91 \times 10^{5}$ to $2.62 \times 10^{5}$. 


\section{Acknowledgments}

The author's team acknowledge all members of the Laboratory of Advanced Physics and Biophysics, Physics Department, Brawijaya University (Malang city, East Java province, Indonesia), for their excellent hands and efforts during the experiment.

\section{Conflict of Interest}

The authors declare no conflict of interest.

\section{References}

1. BUONANNO G., GIOVINCO G., MORAWSKA L., STABILE L. Lung cancer risk of airborne particles for Italian population. Environmental Research, 142, 443, 2015.

2. ALLEN J.L., LIU X., WESTON D., CONRAD K., OBERDÖRSTER G., CORY-SLECHTA D.A. Consequences of developmental exposure to concentrated ambient ultrafine particle air pollution combined with the adult paraquat and maneb model of the Parkinson's disease phenotype in male mice. Neurotoxicology, 41, 80, 2014.

3. CAMARGO E.P. Tropical Diseases. Estudos Avançados, 22, 95, 2008.

4. IKEMOTO T. Tropical malaria does not mean hot environments. Journal of Medical Entomology, 45, 963, 2008.

5. SACHDEV A., GULLA K.M., ANAND K., RAHEJA K., GUPTA N., GUPTA D. Transfluthrin poisoning resulting in intra vascular haemolysis and methemoglobinemia in G6PD deficiency-treatment challenge. Journal of Clinical Toxicology, 5, 5, 2015.

6. MASALU J.P., FINDA M., OKUMU F.O., MINJA E.G., MMBANDO A.S., SIKULU-LORD M.T., OGOMA S.B. Efficacy and user acceptability of transfluthrin-treated sisal and hessian decorations for protecting against mosquito bites in outdoor bars, Parasites \& Vectors, 10, 197, 2017.

7. PAULUHN J., OZAKI K. Transfluthrin: Comparative efficacy and toxicity of reference and generic versions. Regulatory Toxicology and Pharmacology, 71, 1, 2015.

8. PETERSEN R.C. Free-radicals and advanced chemistries involved in cell membrane organization influence oxygen diffusion and pathology treatment. AIMS Biophysics, 4, 240, 2017.

9. IDOWU E.T., AIMUFUA O.J., EJOVWOKE Y., AKINSANYA B., OTUBANJO O.A. Toxicological effects of prolonged and intense use of mosquito coil emission in rats and its implications on malaria control. International Journal of Tropical Biology, 61, 1463, 2013.

10. JANTZEN K., MØLLER P., KAROTTKI D.G., OLSEN Y., BEKÖ G., CLAUSEN G., HERSOUG L.G., LOFT S. Exposure to ultrafine particles, intracellular production of reactive oxygen species in leukocytes and altered levels of endothelial progenitor cells. Toxicology, 359-360, 11, 2016.

11. CHUANG H.C., HO K.F., CAO J.J., CHUANG K.J., HO S.S.H., FENG P.H., TIAN L., LEE C.H., HAN Y.M., LEE C.N., CHENG T.J. Effects of non-protein-type amino acids of fine particulate matter on E-cadherin and inflammatory responses in mice. Toxicology Letters, 237, 174, 2015.
12. UPADHYAY S., GANGULY K., STOEGER T. Inhaled ambient particulate matter and lung health burden. European Medical Journal Respiratory, 2, 88, 2014.

13. LI S., NIU Q., MA R., XU S., PANG L., DING Y., MU L., MI. JING, FENG G., LI F. The relationship between liver dysfunction and arsenic methylation in mice. Polish Journal of Environmental Studies, 24, 4, 2015.

14. KHALILI H.R., BEHROOZ H.R.A., NOOSHABADI M.R.R., GERAVANDI S., MOHAMMADI M.J., FORUOZANDEH H. Evaluation of potential anti-fibrotic effect of oleuropein on bleomycin-induced pulmonary fibrosis in rat. Toxin Reviews, 2018.

15. GOMEZ-TAMES J., FUKUHARA Y., HE S., SAITO K., ITO K., YU W. A human-phantom coupling experiment and a dispersive simulation model for investigating the variation of dielectric properties of biological tissues. Computers in Biology and Medicine, 61, 144, 2015.

16. JACKSON A.R., YUAN T.Y., HUANG C.Y., AND GU W.Y. A conductivity approach to measuring fixed charge density in intervertebral disc tissue. Annals of Biomedical Engineering, 37, 2566, 2009.

17. CAMPANA L.G., CESARI M., DUGHIERO F., FORZAN M., RASTRELLI M., ROSSI C.R., SIENI E., TOSI A.L. Electrical resistance of human soft tissue sarcomas: an ex vivo study on surgical specimens. Medical and Biological Engineering and Computing, 54, 773, 2016.

18. AL AHMAD M., AL NATOUR Z., MUSTAFA F., RIZVI T.A. Electrical characterization of normal and cancer cells. in: IEEE Access. 6, 25979, 2018.

19. WARDOYO A.Y.P., JUSWONO U.P., NOOR J.A.E. Varied dose exposures to ultrafine particles in the motorcycle smoke cause kidney cell damages in male mice. Toxicology Reports, 5, 383, 2018.

20. WARDOYO A.Y.P., JUSWONO U.P., NOOR J.A.E. A study of the correlation between ultrafine particle emissions in motorcycle smoke and mice erythrocyte damages. Experimental and Toxicologic Pathology, 69, 649, 2017.

21. WARDOYO A.Y.P., JUSWONO U.P., NOOR J.A.E. Association of diesel exhaust particle exposure with erythrocytes deformation of male mice. Applied Ecology and Environmental Research, 16, 5, 2018.

22. WARDOYO A.Y.P., JUSWONO U.P., NOOR J.A.E. A study of the correlation between ultrafine particle emissions in motorcycle smoke and mice erythrocyte damages. Experimental and Toxicologic Pathology, 69, 8, 2017.

23. CANNIZZARO V., BERRY L.J., NICHOLLS P.K., ZOSKY G.R., TURNER D.J., HANTOS Z., SLY P.D. Lung volume recruitment maneuvers and respiratory system mechanics in mechanically ventilated mice. Respiratory Physiology and Neurobiology, 169, 243, 2009.

24. WARDOYO A.Y.P., JUSWONO U.P., NOOR J.A.E. How exposure to ultrafine and fine particles of car smoke can alter erythrocyte forms of male mice. Polish Journal of Environmental Studies, 28, 4, 2019.

25. EEFTENS M., PHULERIA H.C., MEIER R., AGUILERA I., CORRADI E., DAVEY M., DUCRET-STICH R., FIERZ M., GEHRIG R., INEICHEN A., KEIDEL D., PROBSTHENSCH N., RAGETTLI M.S., SCHINDLER C., KÜNZLI N., TSAI M.Y. Spatial and temporal variability of ultrafine particles, $\mathrm{NO}_{2}, \mathrm{PM}_{2.5}, \mathrm{PM}_{2.5}$ absorbance, $\mathrm{PM}_{10}$ and $\mathrm{PM}_{\text {coarse }}$ in Swiss study areas. Atmospheric Environment, 111, 60, 2015. 
26. SONNECK R., HORSTMANN S. The impact of resistance in mosquitoes to the efficacy of transfluthrin and other pyrethroids. in: Focus Public Heal. 36, 2017.

27. SODERLUND D.M. Molecular mechanisms of pyrethroid insecticide neurotoxicity. Archives of Toxicology, 86, 165, 2013.

28. GARBA S.H., SHEHU M.M., and Adelaiye A.B. Toxicological effects of inhaled mosquito coil smoke on the rat spleen: A haematological and histological study. Journal of Medical Sciences, 7, 94, 2007.

29. GYAWALI P., RICHARDS R.S., BWITITI P.T., NWOSE E.U. Association of abnormal erythrocyte morphology with oxidative stress and inflammation in metabolic syndrome. Blood Cells, Molecules and Diseases, 54, 360, 2015.

30. RICHARDS R.S., ROBERTS T.K., MCGREGOR N.R., DUNSTAN R.H., BUTT H.L. The role of erythrocytes in the inactivation of free radicals. Medical Hypotheses, 50, 363, 1998.

31. WANG G., JIA S., NIU X., TIAN H., LIU Y., CHEN X., LI L., ZHANG Y., SHI G. Total free radical species and oxidation equivalent in polluted air. Science of the Total Environment, 609, 1103, 2017.

32. FRASER P.A. The role of free radical generation in increasing cerebrovascular permeability. Free Radical Biology and Medicine, 51, 967, 2011.
33. WANG H., HE Y., YANG M., YAN Q., YOU F., FU F., WANG T., HUO X., DONG X., SHI X. Dielectric properties of human liver from $10 \mathrm{~Hz}$ to $100 \mathrm{MHz}$ : normal liver, hepatocellular carcinoma, hepatic fibrosis and liver hemangioma 1. Bio-Medical Materials and Engineering, 24, 2725, 2014

34. BRZEZIŃSKI J., OSZKINIS G., MARZEC E. Dielectric relaxation of a protein-water system in atherosclerotic artery wall. Medical and Biological Engineering and Computing, 45, 525, 2007.

35. MASSIMI M., STAMPELLA A., DEVIRGILIIS L.C., RIZZITELLI G., BARBETTA A., DENTINI M., CAMETTI C. Dielectric characterization of hepatocytes in suspension and embedded into two different polymeric scaffolds. Colloids Surfaces B Biointerfaces, 102, 700, 2013.

36. CHANG F. AND MINC N. Electrochemical control of cell and tissue polarity. Annual Review of Cell and Developmental Biology, 30, 317, 2014.

37. YARDLEY J.E., KELL D.B., BARRETT J., DAVEY C.L., On-line, real-time measurements of cellular biomass using dielectric spectroscopy. Biotechnology and Genetic Engineering Reviewes, 17, 3, 2013.

38. DOWNEY B.J., GRAHAM L.J., BREIT J.F., GLUTTING N.K. A novel approach for using dielectric spectroscopy to predict viable cell volume (VCV) in early process development. Biotechnology Progress, 30, 479, 2013. 